\title{
The life course determinants of vulnerability in late careers
}

\author{
Ignacio Madero-Cabib LIVES Research Centre / Life Course and Inequality Research Centre, \\ Université de Lausanne, Switzerland ignacio.maderocabib@unil.ch
}

(Received April 2014 Revised September 2014)

http://dx.doi.org/10.14301/llcs.v6i1.299

\begin{abstract}
Late career is often seen as a more vulnerable life-stage in the labour market, in which workers may experience a deterioration in job quality. Using a life course perspective and longitudinal data, this article analyses the vulnerability associated with late career by focusing on four occupational dimensions: working-time, career continuity, retirement timing and income change. The research is carried out using data from Switzerland, a country where the age profile of the labour force is an increasing issue. The paper also adopts a cumulative disadvantage perspective to examine the impact of previous work and family life experiences on work life vulnerability at older age. Our data come from the Survey of Health, Ageing and Retirement in Europe (SHARELIFE). The paper uses cluster analysis, sequence analysis and ordered logistic regression. Results show that women with previous family responsibilities resulting in long-term unemployment or caring, often with health complications, are more likely to be vulnerable to deterioration in job quality in late career. This suggests that experiences in the last period of the working life may be just as gendered as earlier periods.
\end{abstract}

Keywords: late careers; vulnerability; cumulative disadvantages; SHARELIFE data; sequence analysis

\section{Introduction}

The labour market is a core focus of life course research. Scholars in the social sciences have particularly focused on the increasing variation in career patterns among individuals. Some examples of career variability include the growth of the female workforce in recent decades associated with part-time working, the rise of flexible contracts, the systematic development of the tertiary sector of the economy and variation in the timing of retirement (Kohli, Rein, Guillemard, \& Van Gunsteren, 1991; Levy, Joye, Guye, \& Kaufmann, 1997).

Life course sociologists often link the analysis of two dimensions of research: the study of the determinants of varying occupational trajectories and the analysis of how such variation leads some individuals to experience more labour market vulnerability in their career. In regard to the first dimension, life course scholars usually focus on factors such as institutional policies in the labour market, interdependence between career and other life domains, and the socially structured timing of work transitions (Levy et al., 1997).
In terms of the second dimension of research, studies often analyse how individual variation in career trajectory benefits some people but harms others. When the consequences are harmful, life course sociologists tend to focus on the notion of social vulnerability. Here, different notions and principles of vulnerability have been proposed (Spini, Hanappi, Bernardi, Oris, \& Bickel, 2013). However, in this paper, we use Castel's notion of vulnerability, which focuses on vulnerability in social integration, particularly in the work sphere (Castel, 2000, 2003, 2009).

Both research dimensions, i.e., the study of vulnerability in occupational life and the analysis of the determinants of varying labour trajectories, have been integrated into international life course research in different career phases (Kohli et al., 1991). In Switzerland, however, life course research has mainly focused on early or middle career (Le Goff, Sapin, \& Camenisch, 2011; Levy, Gauthier, \& Widmer, 2006). Yet in socio-political contexts such as Switzerland, which is characterized by a high rate of participation among older workers (OECD, 2012) and by continuous political reforms aiming to foster an active ageing lifestyle (OFS, 2012a), the issue of 
late career -i.e., having an occupation after age 50 - and specifically, the vulnerability faced in the labour market, are becoming increasingly important.

This paper aims to offer new insights on the study of vulnerability in late career in Switzerland through the lens of Castel's notion of vulnerability. Moreover, in order to measure vulnerability in late career, four occupational dimensions are considered: working-time, career continuity, retirement timing, and income change. More specifically, the aim is to classify vulnerability in each of these dimensions, using both theoretical expectations and empirical classification based on cluster analysis.

Another objective of the paper is the analysis of the determinants of these patterns of vulnerability in late career. Two groups of determinants are studied: life experiences in social domains and what we term 'positional factors' (Levy et al., 1997). The selection of determinants is guided by the theory of cumulative disadvantage in the labour market. This theory proposes that during the life course, cumulative familial and occupational experiences, as well as positional characteristics have consequences in later life (Dannefer, 2003; Sapin, Spini, \& Widmer, 2007).

We use retrospective data from the Survey of Health, Ageing and Retirement in Europe (SHARELIFE) for the analyses. These data permit the application of longitudinal quantitative techniques, such as sequence analysis, to build typical familial and occupational trajectories. We also use ordinal logistic models to analyse the determinants of vulnerability in the labour market in later life.

The paper is organized into five sections. First, Castel's conception of vulnerability is presented and then used to classify vulnerability in late career. Second, a review of the international literature illustrates the impact of risk factors for social vulnerability in the labour market at older age. The third section presents the data, variables and methods used in the paper. In the fourth section, the results of the cluster analyses - which provide an empirical classification of vulnerability in late careers - as well as the sequence analyses and ordinal logistic analyses are presented. The final section offers a discussion of the main findings and prospective research questions.

\section{Castel's notion of vulnerability}

Individual variation in life trajectory often has consequences for social vulnerability (Spini et al., 2013). Castel's notion of vulnerability provides a framework through which to understand these vulnerabilities, that will be applied in this research.

Castel understands vulnerability as a social status which influences the person's integration into society as a function of experiences in two domains: labour market and personal relationships (Castel, 2000). Concretely, a vulnerable status is characterized by insecure employment and fragile social and family networks. Moreover, being defined as vulnerable indicates low social cohesion between the individual and society (Castel, 2003).

The pertinence of Castel's perspective to the life course approach comes from three main points. First, from his comprehensive framework of vulnerability as a status related to social difficulties in gaining access to central institutions of modern society, such as family and work. Secondly, from his understanding of vulnerability not as a status that people experience when they are disaffiliated from social institutions, but rather as a risk for lack of integration into social institutions (Castel, 2000, 2003, 2009). Finally, Castel conceives vulnerability as a contingent status, i.e., as a status that can change over the life course. Indeed, Castel talks about four zones of social life: the integration zone, the vulnerability zone, the assistance zone and the disaffiliation zone. They are defined according to the extent to which people are integrated into the work and relationship domains (Castel, 2000). This schema makes it possible to see vulnerability not necessarily as fixed, but rather as a conditional status. This is why, in this research, vulnerability will be also considered in terms of two other statuses: non-vulnerable and partially vulnerable. Whereas the non-vulnerable status will refer to an individual with good working conditions; partial vulnerability will consider individuals having both good and precarious job conditions.

\section{Using Castel's notion of vulnerability in late careers}

Understanding vulnerability according to Castel's perspective - i.e. as precarious integration into institutions like the labour market - is intrinsically linked to vulnerability in late career.

The low employment rates of workers aged 50 and older are an illustrative example of variation in 
work status during older age. Calculations based on OECD country data (OECD, 2012) reveal that between 1991 and 2012, workers aged 25 to 49 had a labour force participation rate of $81.2 \%$ compared to $59.9 \%$ among workers aged 50 to 64 . New technological demands at work, economic recession, attractive financial incentives for early retirement and firms preferences for hiring younger workers all contribute to the lower employment rates among older workers (Dorn \& Sousa-Poza, 2010; Fischer \& Sousa-Poza, 2006).

We are now also witnessing an increasing proportion of older workers in part-time or temporary jobs which are often associated with lower wages and employment instability (Chan \& Stevens, 2001; Hirsch, Macpherson \& Hardy, 2000). On the one hand, as Feldman (1994) has proposed, these precarious or risky labour conditions for older workers could be part of bridge to retirement in which individuals accept having part-time or provisional jobs before permanently retiring. On the other hand, given that labour markets are usually socially stratified scenarios - often along gendered lines (Meyer \& Pfau-Effinger, 2006) - it is possible that these precarious conditions are more likely to affect more disadvantaged groups, rather than being a phase through which all groups pass.

Bearing in mind these current employment trends, late career is here understood to entail more than the presence or absence of employment. Four occupational dimensions are used to evaluate this career period: working-time, career continuity, retirement timing, and income change. Vulnerability in late careers will be analysed according to these four occupational dimensions. Based on previous research, the following paragraphs provide a number of hypotheses for understanding vulnerability in each of these dimensions.

Working-time. As some research indicates, full-time jobs in the primary labour market are the main contributors to work integration (Hansen, Hespanha, Machado, \& van Berkel, 2002).
However, other studies also suggest that part-time jobs can be considered as alternative sources of integration into the labour market, which, depending on the institutional setting, may be associated with a precarious work situation (O’Reilly \& Fagan, 1998). Given this we hypothesize that partial vulnerability could be linked to both full-time and part-time jobs during the late careers, but define part-time jobs as vulnerable.

Career continuity. As García and Schampheleire (2002) point out, the decreasing amount of formal work during the 1980s and the 1990s generated, in most Western countries, provisional or temporary jobs characterized by flexible occupational status and the reduction of lifelong careers. Consequently, we assume that while non-vulnerable status might refer to a continuous career, partial vulnerability and vulnerability could rather be associated with interrupted careers.

Retirement timing. The literature shows that whereas early retirement is mostly linked to individuals with more advantaged social and economic positions, late retirement is normally a consequence of an interrupted career and is more likely to affect women and employees with low qualifications (Bütler, Huguenin, \& Teppa, 2004; Radl, 2013). Here we hypothesize that while early retirement could reflect a non-vulnerable status, 'on-time' retirement indicates partial vulnerability and late retirement is evidence of a vulnerable status.

Income changes. Taking into consideration the importance of income entitlement for personal autonomy, empowerment, and participation during the occupational career (van Berkel, Hornemann, \& Williams, 2002), it is hypothesized that increases in income indicate a non-vulnerable status in the labour market, while stable income represents partial vulnerability and decreasing income a vulnerable status. Table 1 summarizes the suggested classification of the 'non-vulnerable', 'partially vulnerable', and 'vulnerable' across our four occupational dimensions. 
Table 1. Vulnerability in four occupational dimensions (hypothetical classification)

\begin{tabular}{lccc}
\hline Occupational Dimension & Non-Vulnerable & Partially Vulnerable & Vulnerable \\
\hline Working-Time & Full-time job & Changing-time job & Part-time job \\
Career Continuity & Continuous career & Interrupted career & Interrupted career \\
Retirement Timings & Early retirement & On-Time retirement & Late Retirement \\
Income Changes & $\begin{array}{c}\text { Upward Income } \\
\text { Changes }\end{array}$ & Null Income changes & $\begin{array}{c}\text { Downward Income } \\
\text { Changes }\end{array}$ \\
\hline
\end{tabular}

The different occupational dimensions are classified according to level of vulnerability. The question of how these dimensions are associated with one another will be addressed using a cluster analysis model that will be presented in the results section.

\section{Switzerland as a research case for the study of late careers}

Switzerland is an ideal research case for this paper since it has a number of institutional mechanisms promoting the extended work life or, as it is formally called, 'active ageing' (OFS, 2012b). This refers to various public policies and market incentives aimed at discouraging early withdrawal from the labour market and also fostering career continuity after the state pension age. As in other European countries, in Switzerland the policies are a result of a declining birth rate and increasing average age, combined with growing financial instability of public spending and private pension funds (Hanel, 2010).

Specifically in Switzerland, the active ageing mechanisms include: the current option of accumulating public pension funds beyond the state pension age (till age 69 for women and 70 for men), financial benefits in the context of occupational pension funds in the event of late withdrawal, financial penalties for early retirement and financial exemptions for late retirement provided by the public pension fund. Finally, training policies in various sectors of the Swiss economy aim to improve the labour skills of older workers (OFS, 2012b, 2012c, 2012d).

From an international point of view, Switzerland is a country with a large proportion of older workers. As Figure 1 shows, in comparison with other OECD countries, Switzerland has a high rate of active workers aged 50 to 64 . Figure 1 also indicates that within the 5-year divisions of that age range (e.g. 50-54, 55-59 or 60-64), the larger proportion of older workers in Switzerland than in the rest of the $O E C D$, has remained consistent for more than 20 years. Yet, in the age category 60-64 the participation rate in the Swiss labour market fluctuates around 55\%, which prompted the development of incentives for active ageing. 
Figure 1. Labour participation rate by age class in Switzerland and OECD countries between years 1991 and 2012

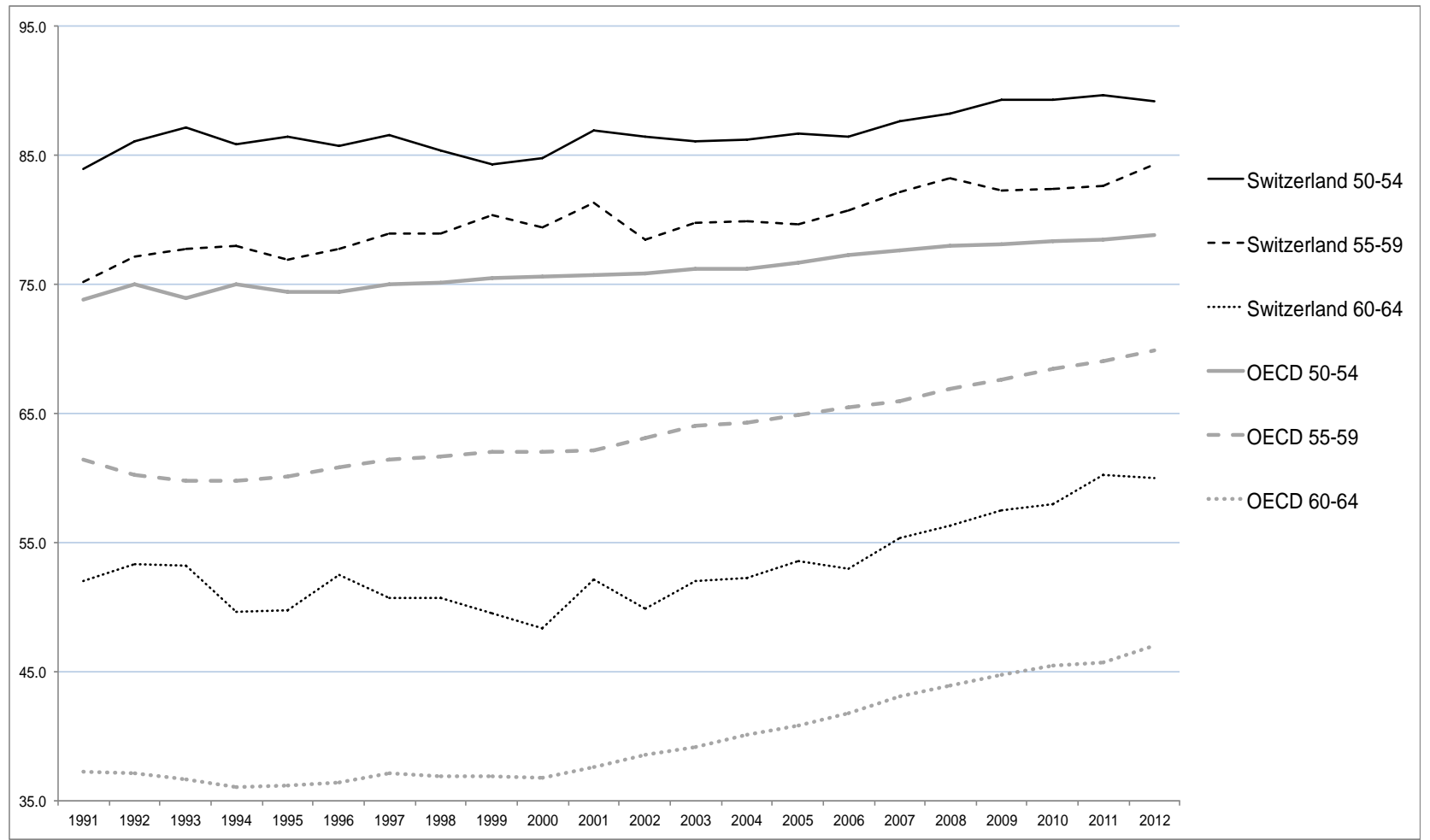

Source: Author calculations based on data from OECD (OECD, 2012)

Both the large number of older workers and the institutional aim of fostering the career continuity of older workers have caused the recent occupational period in Switzerland to be a topic of increasing importance for research. This is not only because it provides an opportunity to extend the vast literature on early and middle adulthood careers but also because it provides an opportunity to gain insight into the particular dynamics of vulnerability at older age.

\section{Life course determinants of \\ vulnerability in late careers}

As well as studying the distribution of vulnerability in late career, another aim of this research is to explore the determinants of vulnerability at older age. As mentioned, the cumulative disadvantage perspective theoretically supports the choice of considering particular life course determinants of vulnerability.

This theoretical approach assumes that social differences among people were not imposed at birth, but that they progressively developed during the life course through a cumulative process and then contribute to the likelihood of later life transitions (Dannefer, 2003). Put descriptively, small inequalities in health, social networks, family duties, socio-cultural backgrounds, and professional status, when accumulated and combined, could produce socially differentiated trajectories across the lifecourse (Sapin et al., 2007).

In this paper, the selected life course factors are life experiences in social domains and positional factors. The first refers to those individual events, transitions or trajectories that people experience in domains such as education, family, occupation, or political spheres (Levy et al., 1997). The second, positional factors, should be understood as those determinants that comprise an individual's position in dimensions of social stratification (Blau, 1977). These include positional or stratifying characteristics such as birth cohort, gender, ethnicity, cultural background, or socio-economic conditions, which, when taken together, provide a more or less privileged position for each individual in society.

We now review the international literature on the impact of life course determinants on vulnerability in late career. This review considers the occupational dimensions working-time, career continuity, retirement timing, and income changes. 


\section{Influence of life experiences in social domains on vulnerability in late careers}

Research on the life course suggests that particular life experiences can have a large impact on later employment experience (Hyde, Ferrie, Higgs, Mein, \& Nazroo, 2004). This research specifically focuses on two dimensions of life experience. The first is financial well-being: pension contributions, periods of financial hardship and periods of ill-health. The second focuses on familial and occupational experiences before older age. The first dimension we label financial well-being indicators, and the second familial and occupational trajectories.

In terms of financial indicators, the literature suggests that beneficial conditions such as progressive access to pension plans and the absence of periods of financial hardship are associated with a later career characterized by fulltime employment and early retirement (Gowan, 1998; Radl, 2013). Periods of ill-health may be an important factor here. Research suggests that although there is some variation according to the economic sector, in the majority of occupations, workers with health disabilities are more likely to retire early and also to interrupt their careers due to physical disability (Dorn \& Sousa-Poza, 2004a).

With regard to the family and labour market determinants of vulnerability, some studies indicate that for women, a familial trajectory marked by marriage and parenthood generates later career patterns, with part-time jobs, an interrupted career and 'on-time' or late retirement (Hirsch et al., 2000; Hyde et al., 2004; O'Rand \& Henretta, 1982). Additionally, occupational trajectories characterized by long-term employment, working continuously as a civil servant or in occupations with higher occupational prestige such as professional jobs, are associated with early retirement, continuous careers, and full-time jobs in the last occupational period (Dorn \& Sousa-Poza, 2004b; Madero-Cabib, Gauthier, \& Le Goff, 2013).

\section{Influence of positional factors on vulnerability in late careers}

Studies of older people in the labour market have shown that men are more likely than women to occupy advantaged labour positions and to experience increasing income and continuous careers (Han \& Moen, 1999; Riley, 1986). Similarly, native citizenship versus being a non-national is usually linked to the experience of a continuous career development with an upward income trajectory (Madero-Cabib \& Mora, 2011).

Research also indicates that people occupying higher social class positions are more likely to have later careers, characterized by advantaged working conditions including full-time jobs, continuous careers, and upward changes of income (Bukodi \& Goldthorpe, 2011; Radl, 2013).

Finally, studies focused on the impact of different birth cohorts on careers, demonstrate that people belonging to older birth cohorts (19201940) were more likely to experience the economic and structural opportunities associated with the 'thirty glorious years' between 1945 and 1975 (Chauvel, 1998). This may have made them more likely to enjoy an uninterrupted career in their later work life, involving upward income changes and early retirement.

\section{Data, variables, and methods Data}

The data used for the current study come from the Survey of Health, Ageing, and Retirement in Europe (SHARE), and specifically from the third wave named SHARELIFE, which has a retrospective design and was carried out in 2008-2009. The SHARELIFE survey collected information on individuals aged $50+$ and collected information on different dimensions over the course of their lives including family composition, occupation characteristics, health care, retirement, and other life aspects (Schröder, 2011). Data collection for SHARELIFE was based on probabilistic sampling and face-to-face interviews using life history calendars. These helped respondents to remember, and chronologically organize, the various episodes of their lives, given people's usual difficulty in accurately remembering early life events (Schröder, 2011).

The Swiss sample of SHARELIFE is composed of 1,296 individuals. The specific sample used in this study consisted of people who effectively worked in Switzerland in an occupation after age 50 and who also fitted the substantive criteria concerning the four occupational dimensions under investigation. This means that the population of interest of this study is people who worked in a full-time or parttime position (working-time), who had continuous or interrupted careers (career continuity), who retired early, 'on-time' or late (retirement timing), 
and who did or did not experience variations in their incomes (income changes). Consequently, the study sample consists of 451 individuals. As Appendix 1 indicates, the study sample and the Swiss sample of SHARELIFE are very similar, considering the different financial and positional characteristics. The observed differences in the proportions of birth cohorts between both samples arise because in the study sample only retired people were included, while the Swiss sample of SHARELIFE includes individuals aged 50 and older. The study sample represents $97 \%$ of retirees included in the Swiss data of SHARELIFE.

However, Appendix 1 shows a notable difference between the two samples in terms of gender proportions: whereas in the study sample $60.3 \%$ are men and $39.7 \%$ women, in the Swiss sample of SHARELIFE $45.9 \%$ are men and $54.1 \%$ women. This gender distribution is probably due to the strong male breadwinner model in Switzerland, which usually entails low female participation in the labour market, especially during the life courses of the cohorts under study (Le Feuvre, Kuehni, Rosende, \& Schoeni, 2014; Kuehni, Rosende, \& Schoeni, 2013; Rosende \& Schoeni, 2012).

In other words, a considerable proportion of the women included in the Swiss sample of SHARELIFE probably followed a traditional family trajectory, e.g. marriage and children's births, which meant they experienced either extended periods out of the labour force or left the labour market early in life. Hence, given that the research focus is on active people after age 50 , women who withdrew from the labour market due to family responsibilities or other issues before that age are excluded from the analysis.

In order to avoid potential selection bias caused by differential non-response, that could lead to erroneous or non-representative results, this sample was weighted according to the strategy recommended by SHARE, namely using calibrated weights (Deville \& Särndal, 1992). As mentioned in the SHARE 2.5.0 guide, calibrated weights provide weights that are as close as possible to the original sampling design weights, while also respecting a set of known population totals. However, given the large debate in the scientific literature about the effectiveness of weighting in regression analysis (see for example Solon, Haider \& Wooldrige, 2013) it should be noted that this is a measure that only partially reduces non-response biases.

\section{Variables}

Dependent variable. The dependent variable in this study is an ordinal variable with three levels: 1=non-vulnerable, 2 =partially vulnerable, and

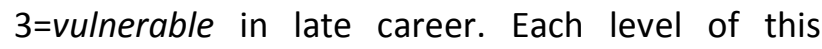
variable corresponds to a cluster resulting from the construction of a three-cluster analysis, which is explained in depth in the Methods section below.

Covariates. In accordance with the international literature review and the cumulative disadvantage perspective, the covariates for the study correspond to three life course factors: financial well-being indicators, familial and occupational trajectories, and positional factors. As shown in Table 2, specific variables operate as proxies for the three covariates mentioned. The first covariate concerns contribution to pension funds, periods of financial hardship and periods of ill-health. The second covariate brings together familial and occupational trajectories - which are described in the Results section - and the third covariate groups together the stratification variables.

In Table 2, the choice of contributions to pension funds as a proxy of financial status is based on the evidence that in Switzerland the possibility of having access to the three types of pension funds is strongly associated with the financial status of each individual. The public pension system is mandatory for every individual living in Switzerland but those with very low incomes often do not contribute (OFS, 2012a). The occupational pension fund is available only to employees and civil servants with annual salaries higher than 20,880 Swiss Francs (i.e. $\$ 22,854$ or $€ 16,920)$. Finally, private pension funds are often used by the self-employed or by employees and civil servants with enough income to invest. Moreover, because the sample is composed of already-retired individuals, these are pension investments made during their late careers. 
Table 2. Covariates

\begin{tabular}{|c|c|c|}
\hline Covariate & Proxy Covariates & Operationalization and Weighted Frequencies \\
\hline \multirow{5}{*}{$\begin{array}{l}\text { Financial } \\
\text { and } \\
\text { Well-Being } \\
\text { Indicators }\end{array}$} & Contribution to public pension fund & $\begin{array}{l}\text { 1: More than half of late careers }(94.5 \%) \\
0: \text { Less than half of late careers }(5.5 \%)\end{array}$ \\
\hline & Contribution to occupational pension fund & $\begin{array}{l}\text { 1: More than half of late careers }(54.1 \%) \text {, } \\
0: \text { Less than half of late careers }(45.9 \%)\end{array}$ \\
\hline & Contribution to private pension fund & $\begin{array}{l}\text { 1: More than half of late careers }(8.2 \%) \text {, } \\
0: \text { Less than half of late careers }(91.8 \%)\end{array}$ \\
\hline & III-health periods & $0:$ No $(89.8 \%), 1:$ Yes $(10.2 \%)$ \\
\hline & Financial hardship periods & 0: No (69.3\%); 1: Yes (30.7\%) \\
\hline \multirow{13}{*}{$\begin{array}{l}\text { Familial and } \\
\text { Occupational } \\
\text { Trajectories }\end{array}$} & Marriage \& One Child & 1: Belonging (12\%), 0 : Not belonging $(88 \%)$ \\
\hline & Marriage \& Two Children & 1: Belonging $(31.2 \%), 0$ : Not belonging $(68.8 \%)$ \\
\hline & Marriage \& Three or More Children & 1: Belonging (31.1\%), 0: Not belonging $(68.9 \%)$ \\
\hline & Solo Living & 1: Belonging (9.3\%), 0: Not belonging $(90.7 \%)$ \\
\hline & Marriage \& Divorce & 1: Belonging (12.5\%), 0 : Not belonging $(87.5 \%)$ \\
\hline & Late Marriage & 1: Belonging (3.8\%), 0: Not belonging (96.2\%) \\
\hline & Service Employee Careers & 1: Belonging (21.8\%), 0 : Not belonging $(78.2 \%)$ \\
\hline & Technician Employee Careers & 1: Belonging (35.9\%), 0 : Not belonging $(64.1 \%)$ \\
\hline & Professional Employee Careers & 1: Belonging (9.1\%), 0: Not belonging $(90.9 \%)$ \\
\hline & Interrupted Careers \& Non-Careers & 1: Belonging (14.9\%), 0: Not belonging (85.1\%) \\
\hline & From Employee to Self-Employed & 1: Belonging (8.1\%), 0: Not belonging (91.9\%) \\
\hline & Technician Civil-Servant Careers & 1: Belonging (5.9\%), 0 : Not belonging $(94.1 \%)$ \\
\hline & Professional Civil-Servant Careers & 1: Belonging (4.3\%), 0: Not belonging (95.7\%) \\
\hline \multirow{5}{*}{$\begin{array}{l}\text { Positional } \\
\text { Factors }\end{array}$} & Gender & 1: Men (60.3\%), 0: Women (39.7\%) \\
\hline & $\begin{array}{l}\text { Sociocultural Background: Educational position relative } \\
\text { to others in maths during childhood }\end{array}$ & $\begin{array}{l}\text { 1: Better or Much Better (88.8\%), 0: Much } \\
\text { worse, Worse or About the same (11.2\%) }\end{array}$ \\
\hline & $\begin{array}{l}\text { Sociocultural Background: Educational position relative } \\
\text { to others in language during childhood }\end{array}$ & $\begin{array}{l}\text { 1: Better or Much Better ( } 86.4 \%), 0: \text { Much } \\
\text { worse, Worse or About the same }(13.6 \%)\end{array}$ \\
\hline & $\begin{array}{l}\text { Sociocultural Background: Number of books in home in } \\
\text { childhood }\end{array}$ & $\begin{array}{l}1: 26 \text { books or more }(83.1 \%), 0 \text { : Fewer than } 26 \\
\text { books }(16.9 \%)\end{array}$ \\
\hline & Birth Cohort & $\begin{array}{l}\text { 1: Before } 1930(27.4 \%), 2: 1931-1936(23.4 \%) \text {, } \\
\text { 3:1936-1942 (29.8\%), 4: After } 1942(19.3 \%)\end{array}$ \\
\hline
\end{tabular}

\section{Methods}

Three different research methods were applied: first, cluster analysis was used to build the dependent variable. Second, sequence analysis was used to construct familial and occupational trajectories. Third, ordered logistic regression was used to estimate the effects of covariates on the dependent variable.

The statistical association between work-time basis, career continuity, retirement timing, and income changes was measured using cluster analysis. However, before applying the cluster analysis, it was necessary to analyse each occupational dimension throughout the later career. Working-time, career continuity and income changes are dimensions built from the examination of variation among different jobs during the later work career. To this end, a longitudinal database with annual workers' occupational information from age 51 up to retirement was constructed. To measure income variation among jobs the first monthly income in the job was considered. Retirement timing was coded into three different categories: 'early', 'on-time', and 'late' retirement. These categories were built, taking into consideration the fact that the legal age of retirement in Switzerland is different for women and men, and that this difference has changed over time (Candolfi \& Chaze, 2008).

Once the information for the four occupational dimensions for the career period was obtained, the indicators for these dimensions were converted into different dichotomous variables, which were introduced into the cluster model. A k-means clustering method was used. The cluster analysis then allowed three clusters to be identified, which were associated with the statuses non-vulnerable, partially vulnerable, and vulnerable.

The second method used in this research is sequence analysis. This technique creates 
typologies of longitudinal patterns from sequences of life-course events in domains such as family, education, political and occupation. The method creates types of individual trajectories in a certain domain by comparing them according to their similarity or dissimilarity across individuals. In technical terms, sequence analysis works by creating matrices of individual sequences composed of different social statuses, and measuring the distance between all pairs of individual sequences. The method used to measure these distances is optimal matching analysis (OMA). In order to calculate those distances we used specifically the constant substitution costs of 2 and indel costs of 1 to balance the importance of the order of statuses and the timing of changes between statuses in each kind of sequence (Blanchard, Bühlmann, \& Gauthier, 2014). It is possible to perform a cluster analysis on the resulting distance matrix, which allows homogeneous groups of sequences to be created, which, taken together, represent types of trajectories (Blanchard et al., 2014). The clustering method used to agglomerate trajectory types was 'Ward' (Ward, 1963), and the average silhouette width higher than 0.5 as the cut-off criterion of trajectory types was used (Kaufman \& Rousseeuw, 1990).

In the study presented here, types of familial and occupational trajectories from age 20 to 49 were constructed. The events or statuses for building these trajectories were chosen based on the family and work determinants of vulnerability in late career, highlighted in the literature. Familial trajectories were built according to five indicators: 1) marriage, 2) divorce, 3) children, 4) cohabitating partners, and 5) non-cohabitating partners. Meanwhile, occupational trajectories were built based on three indicators: 1) out of the labour market, e.g. housework or unemployment, 2) employment status, e.g., employee, civil servant, and self-employed, and 3) type of occupation, e.g., professionals (legislator, senior official or manager, professional), technicians (technician or associated professional, clerk, armed forces, skilled agricultural or fishery worker, craft or related trades worker), and service occupations (service, shop or market sales worker, plant/machine operator or assembler, elementary occupation). Both in the case of familial and occupational trajectories, in order to construct individual sequences according to the indicators mentioned, each individual was measured according to age at beginning, age at end, and status in every indicator.

The third method used in this study is ordered logistic regression. As Long (1997) has pointed out, one of the main reasons to use this technique is the opportunity to examine how different covariates impact on an ordinal variable taking into account all its values simultaneously. In the present research, since a higher value (value 3 ) relates to a vulnerable status, results will be interpreted as the likelihood of experiencing that status given the other two, i.e., non-vulnerable and partially vulnerable. One crucial assumption made is the proportional odds associated with any independent predictor are assumed to be the same over all levels of the dependent variable (Long, 1997). This means, for instance, that the regression estimate of any covariate on the odds of being non-vulnerable or partially vulnerable will be identical.

In this research, those predictor variables that did not have valid values for the entire range of the dependent variable were automatically removed from the ordered regression models as the proportional odds assumption could not be tested. This was the case for the familial type 'solo living', the occupational type 'service employee careers' and 'professional and technician civil-servant careers'. As well as considering the common difficulty of implementing the proportional odds assumption (see for instance Peterson \& Harrell, 1990), covariates showing a difference of regression estimates at most 2.2 on the pairs of values of the dependent variable were tolerated. By using the Phi coefficient, the correlation between covariates was controlled, and only one covariate ('birth cohort 1936-1942') was removed from the regression model due to a moderate-positive association with two other covariates, i.e. equal to or higher than 0.4 (Dancey \& Reidy, 2004). Finally, covariates with many missing values such as social class, educational level and ethnicity, were not included in the regression models of this study.

All computations presented here are made using the $R$ statistical software ( $R$ Core Team, 2012) together with the libraries svytable-for calculating weighted univariate frequencies-Cluster-for performing cluster analysis-TraMineR-for carrying out sequence analysis (Gabadinho, Ritschard, Müller, \& Studer 2011)-and svyolr-for estimating weighted ordinal logistic regressions. 


\section{Results}

\section{Cluster analysis of vulnerability in late careers}

Table 3 presents different criteria according to which the three-cluster solution performed better than, or similarly to, the cluster solutions with two, four and five conglomerates. It indicates that after three clusters, the criteria to measure robustness of cluster solutions only marginally improved. Thus, three groups appeared to be an acceptable solution for the patterning among the four occupational dimensions of later career.

Table 3. Comparison of different cluster solutions

\begin{tabular}{lcccc}
\hline Criterium & 2 Clusters & 3 Clusters & 4 Clusters & 5 Clusters \\
\hline Average distance between clusters & 8.93 & 5.10 & 5.95 & 5.99 \\
Average distance within clusters & 3.36 & 2.71 & 2.25 & 2.43 \\
Average silhouette & 0.61 & 0.41 & 0.45 & 0.45 \\
Entropy & 0.18 & 0.77 & 0.84 & 0.82 \\
\hline
\end{tabular}

Table 4 shows the cluster analysis with three conglomerates. As observed, a first conglomerate groups those individuals with upward income changes, full-time jobs, continuous careers, and 'on-time' retirement. This cluster was called nonvulnerable. A second conglomerate, entitled partially vulnerable, comprised those with null income changes, full-time jobs, continuous careers, and early retirement. A third conglomerate, named vulnerable, groups people with downward income changes, changing-time jobs, interrupted careers, and late retirement.

Table 4. Contribution of indicators of four occupational dimensions to each cluster

\begin{tabular}{lcccccc}
\hline \multicolumn{1}{c}{ Cluster } & $\begin{array}{c}\text { Upward Income } \\
\text { Changes }\end{array}$ & Null Income Changes & $\begin{array}{c}\text { Downward Income } \\
\text { Changes }\end{array}$ & Full-Time Job & Part-Time Job & Changing-Time Job \\
\hline 1. Not-Vulnerable & 0.058 & -0.048 & -0.009 & 0.089 & -0.082 & -0.028 \\
2. Partially Vulnerable & -0.062 & 0.080 & -0.050 & 0.047 & -0.021 & -0.048 \\
3. Vulnerable & 0.553 & -0.890 & 0.813 & -1.284 & 0.844 & 0.913
\end{tabular}

\begin{tabular}{lccccc}
\multicolumn{1}{c}{ Cluster } & Interrupted Career & Continuous Career & Early Retirement & "On-Time" Retirement & Late Retirement \\
\hline 1. Not-Vulnerable & -0.215 & 0.215 & -1.080 & 1.512 & -0.432 \\
2. Partially Vulnerable & -0.215 & 0.215 & 0.511 & -0.660 & 0.133 \\
3. Vulnerable & 4.637 & -4.637 & -0.679 & 0.100 & 0.802
\end{tabular}

Note. Indicators of occupational dimensions with the higher contribution in each cluster are highlighted in grey.

There is a satisfactory association between the hypothetical classification of the four occupational dimensions of vulnerability (Table 1 ) and the empirical results of the cluster analysis. Thus the idea of studying late careers by distinguishing three different levels of vulnerability within the labour market continues to be valuable. It is noteworthy that the status vulnerable still represents those people who are in precarious work conditions, while non-vulnerable is associated with good labour status, and partially vulnerable presents good but not necessarily excellent job characteristics such as null income changes.

\section{Familial and occupational trajectories}

In this subsection, tables with summary information about familial and occupational trajectories are displayed. However, Appendices 2 and 3 present graphics of both familial and occupational trajectories, that provide more details of the longitudinal paths.

Types of familial trajectories. As Table 5 indicates, six familial types are specifically constructed. $A$ 
priori, the majority of familial trajectories appear to be associated with marriage and parenthood. Indeed, Type I, named Marriage \& One Child (share $=12.0 \%$ ), Type II, named Marriage \& Two Children (share $=31.2 \%$ ), and Type III, Marriage \& Three or More Children (share $=31.1 \%$ ) show people who are married and the parent, respectively, of one child (Type I), two children (Type II), and three or more children (Type III) from age 26 on average. Table 5 also shows that there are more men than women in these three familial types, which could be linked to the gender proportions in the study sample.

Table 5. Types of familial trajectories in Switzerland between ages 20 and $\mathbf{4 9}$

\begin{tabular}{lccc}
\hline Familial Type & Weighted Share (\%) & Women (\%) & Men (\%) \\
\hline I. Marriage \& One Child & 12.0 & 43.3 & 56.7 \\
II. Marriage \& Two Children & 31.2 & 33.3 & 66.7 \\
III. Marriage \& Three or More Children & 31.1 & 35.8 & 64.2 \\
IV. Solo Living & 9.3 & 51.4 & 48.6 \\
V. Marriage \& Divorce & 12.5 & 42.2 & 57.8 \\
VI. Late Marriage & 3.8 & 76.6 & 23.4 \\
\hline
\end{tabular}

Moreover, Type IV (share=9.3\%) was called Solo Living since it corresponds to the type gathered over the entire period of a sizeable proportion of individuals living alone. Type $\mathrm{V}$, named Marriage \& Divorce (share $=12.5 \%$ ) indicates those persons being married and beginning to be divorced from age 35. Finally, Type VI, entitled Late Marriage (share $=3.8 \%$ ) groups individuals following what could be called a 'non-traditional' relationship, i.e., having cohabitation or non-cohabitation partners and then marrying but later than people in the previous types. As Table 5 reveals, only the last familial type shows a clear gender division, with women representing more than three quarters of the type.
Types of occupational trajectories. Table 6 shows that are seven types of occupational trajectories. At first sight, large numbers of employees and low rates of unemployment characterize most occupational trajectories. For instance, Type I, called Service Employee Careers (share $=21.8 \%$ ), Type II, called Technician Employee Careers (share $=35.9 \%$ ), and Type III, called Professional Employee Careers (share $=9.1 \%$ ), show that many people start their careers working as service, technician and professional employees and remain in those statuses until the end of the time period considered. In terms of gender differentiation, the second and third occupational types show a higher presence of men than women.

Table 6. Types of occupational trajectories in Switzerland between ages 20 and $\mathbf{4 9}$

\begin{tabular}{lccc}
\hline Occupational Type & Weighted Share (\%) & Women (\%) & Men (\%) \\
\hline I. Service Employee Careers & 21.8 & 50.5 & 49.5 \\
II. Technician Employee Careers & 35.9 & 25.2 & 74.8 \\
III. Professional Employee Careers & 9.1 & 23.4 & 76.6 \\
IV. Interrupted Careers \& Non-Careers & 14.9 & 79.3 & 20.7 \\
V. From Employee to Self-Employed & 8.1 & 44.7 & 55.3 \\
VI. Professional Civil-Servant Careers & 4.3 & 24.5 & 75.5 \\
VII. Technician Civil-Servant Careers & 5.9 & 17.5 & 82.5 \\
\hline
\end{tabular}


Moreover, Type IV, entitled Interrupted Careers \& Non-Careers (share=14.9\%) is the only cluster containing a considerable proportion of individuals either being permanently outside the labour market or interrupting their careers notably between ages 25 and 40. This is the only occupational type in which women are in a clear majority. Type $\mathrm{V}$, called From Employee to Self-Employed (share $=8.1 \%$ ), groups those self-employed workers who started their careers as employees. Finally, Types VI and VII, entitled respectively Professional Civil-Servant Careers (share $=4.3 \%$ ) and Technician Civil-Servant Careers (share $=5.9 \%$ ), refer to those individuals continuously working as civil servants during the period considered. Table 6 indicates that it is largely men who constitute these two last occupational types.

\section{Ordinal logistic models of vulnerability in late careers}

The effects of the covariates on the ordinal dependent variable are estimated through ordered logistic modelling. Given the gender differentiation of familial and occupational trajectory types, gender interaction effects with different trajectories are tested within the models. Our analyses begin by measuring the impact of familial and occupational trajectories along with gender interaction effects, followed by the effects of financial, well-being and positional factors in additional models.

Considering Model 3 of Table 7, what can be observed first is that those individuals grouped in the familial type Marriage \& Divorce and in the occupational types Interrupted Careers \& NonCareers and Professional Employee Careers are clearly more likely to experience vulnerable statuses in late career. However, gender interaction effects show that the positive influence of types Marriage \& Divorce and Professional Employee Careers on vulnerability is significantly stronger in the case of women. Equally, gender interaction effects reveal that women in the occupational type From Employee to Self-Employed also tend to be more vulnerable in late career. Furthermore, it is important to note that women largely constitute the occupational type Interrupted Careers \& NonCareers.

These first results suggest that those women who worked mostly as an employee, who experienced divorce and/or unemployment or periods working in the home, have a higher likelihood of experiencing a downward income trajectory, career interruption, late retirement, and part-time work during their later work life. Based on previous Swiss research, this evidence can be preliminarily explained by the current sexual division of the Swiss labour market. This division creates the condition in which women with family obligations are more likely to have an interrupted career and part-time jobs, and conversely, assures a stable occupational status, i.e., full-time jobs, wage increases and continuous careers, for men (Le Feuvre et al., 2014; Kuehni et al., 2013; Rosende \& Schoeni, 2012).

Going further, men are much less likely to experience career interruption due to birth or family life events (Le Goff et al., 2011). Being male is also associated with better occupational conditions in terms of continuity of contribution to public, occupational, and private pension funds, which then allows earlier retirement (Rosende \& Schoeni, 2012).

Model 3 of Table 7 suggests that individuals with at least one period of ill-health in their life are more likely to experience a period of vulnerability in late career. This effect could be explained by personal necessity and the institutional context that fosters career interruptions and downward income changes for those individuals who are affected by health problems (Dorn \& Sousa-Poza, 2004a).

Finally, Model 3 of Table 7 indicates that people born before 1930 are less likely to experience vulnerability in late career. This result is congruent with the above-mentioned economic and structural opportunities of the 'thirty glorious years' experienced by those who started work between 1945 and 1975 (Chauvel, 1998). Such opportunities meant that these individuals faced more benign labour market conditions in the later career. 
Table 7. Ordinal logistic regression of vulnerability in late careers (Dependent variable: 1 ) NonVulnerable, 2) Partially Vulnerable 3) Vulnerable. Coefficients in odds ratios)

\begin{tabular}{|c|c|c|c|}
\hline Covariates & Model 1 & Model 2 & Model 3 \\
\hline \multicolumn{4}{|l|}{ Familial Trajectory Types (Reference: Marriage \& Two Children) } \\
\hline Marriage \& One Child & $2.89(0.75)$ & - & $2.88(0.74)$ \\
\hline Marriage \& Three or More Children & $1.18(0.51)$ & - & $1.26(0.53)$ \\
\hline Late Marriage & $2.64(0.68)$ & - & $2.91(0.78)$ \\
\hline Marriage \& Divorce & $3.46(0.61)^{*}$ & - & $3.14(0.60)+$ \\
\hline \multicolumn{4}{|l|}{ Occupational Trajectory Types (Reference: Technician Employee Careers) } \\
\hline Interrupted Careers \& Non-Careers & $3.89(0.66)^{*}$ & - & $4.21(0.69)^{*}$ \\
\hline Professional Employee Careers & $7.26(0.49)^{\star * *}$ & - & $7.27(0.54)^{* * *}$ \\
\hline From Employee to Self-Employed & $2.80(0.65)$ & - & $3.20(0.74)$ \\
\hline \multicolumn{4}{|l|}{ Gender Interaction Effects with Family and Occupational Trajectory Types } \\
\hline Gender. Men (1) vs Women (0) & $1.59(0.37)$ & - & $1.61(0.37)$ \\
\hline Marriage \& One Child * Gender & $0.42(0.86)$ & - & $0.45(0.86)$ \\
\hline Marriage \& Three or More Children * Gender & $0.60(0.58)$ & - & $0.59(0.61)$ \\
\hline Late Marriage * Gender & $1.14(0.73)$ & - & $1.26(0.85)$ \\
\hline Marriage \& Divorce * Gender & $0.30(0.71)+$ & - & $0.31(0.71)+$ \\
\hline Interrupted Careers \& Non-Careers * Gender & $0.47(0.81)$ & - & $0.46(0.83)$ \\
\hline Professional Employee Careers * Gender & $0.18(0.63)^{\star *}$ & - & $0.17(0.66)^{\star *}$ \\
\hline From Employee to Self-Employed * Gender & $0.17(0.78)^{*}$ & - & $0.17(0.88)^{*}$ \\
\hline \multicolumn{4}{|l|}{ Financial, Well-Being and Positional Covariates } \\
\hline $\begin{array}{l}\text { Contribution to public pension fund. More than half of late careers (1) vs less the half } \\
\text { of late careers (ref) }\end{array}$ & - & $0.61(0.50)$ & $0.69(0.62)$ \\
\hline $\begin{array}{l}\text { Contribution to occupational pension fund. More than half of late careers (1) vs less } \\
\text { than half of late careers (ref) }\end{array}$ & - & $1.06(0.22)$ & $1.18(0.24)$ \\
\hline $\begin{array}{l}\text { Contribution to private pension fund. More than half of late careers (1) vs less than } \\
\text { half of late careers (ref) }\end{array}$ & - & $1.09(0.33)$ & $1.04(0.34)$ \\
\hline Financial hardship periods. Yes (1) vs No (ref) & - & $1.22(0.23)$ & $1.27(0.24)$ \\
\hline III-health periods. More than one period (1) vs No periods of health illnesses. (ref) & - & $1.92(0.36)+$ & $2.16(0.35)^{*}$ \\
\hline $\begin{array}{l}\text { Educational position relative to others in Maths during childhood. Better or Much } \\
\text { Better (1) vs Much worse, Worse or About the same (ref) }\end{array}$ & - & $0.61(0.38)$ & $0.60(0.41)$ \\
\hline $\begin{array}{l}\text { Educational position relative to others in Language during child-hood. Better or Much } \\
\text { Better (1) vs Much worse, Worse or About the same (ref) }\end{array}$ & - & $1.72(0.28)+$ & $1.41(0.31)$ \\
\hline $\begin{array}{l}\text { Socio-Cultural Background: Number of books in home in childhood. } 26 \text { books or more } \\
\text { (1) vs less than } 26 \text { books (ref) }\end{array}$ & - & $0.81(0.26)$ & $0.86(0.28)$ \\
\hline Birth Cohort: < 1930 (1) vs > 1936 (ref) & - & $0.52(0.28)^{*}$ & $0.56(0.30)+$ \\
\hline Birth Cohort: 1931-1936 (1) vs > 1936 (ref) & - & $0.71(0.26)$ & $0.76(0.27)$ \\
\hline Observations & 450 & 450 & 450 \\
\hline
\end{tabular}

Notes: Significant coefficients in grey $\left({ }^{* *}: \mathrm{p}<.001 ;{ }^{* *}: \mathrm{p}<.01 ;^{*}: \mathrm{p}<.05 ;+\mathrm{p}<.10\right)$. Standard errors of logits in brackets.

\section{Summary and discussion}

The study of occupational careers has been a particular focus of life course sociology. The study of the determinants of careers and the analysis of vulnerability experienced by some workers, has attracted the attention of many life course scholars.

However, most studies of labour market vulnerability have focused on early and middle adulthood, whereas this article aimed at examining the patterning and determinants of vulnerability in late careers, focusing specifically on the Swiss case.
In this article, Castel's notion of vulnerability was employed to understand the impact of different dimensions of vulnerability on social integration in society. These dimensions include having an insecure job and fragile relationship networks. Moreover, in order to measure vulnerability in late career, this study focused on four occupational dimensions: working-time, career continuity, income changes and retirement timing.

The first aim of this research was to understand how vulnerability could be understood in terms of 
the four occupational dimensions above. After performing cluster analysis with a threeconglomerate solution, it was found that vulnerability involved a cluster grouping of workers with downward income trajectories, a move to part-time employment, interrupted careers and late retirements.

Furthermore, this research also aimed to analyse, through ordered logistic models, how different life course factors such as familial and occupational trajectories, financial well-being and positional indicators impacted on vulnerability in late career. The selection of those determinants was theoretically supported by the cumulative disadvantage perspective, which proposes that during the life course, cumulative familial and occupational experiences as well as the positional characteristics of workers can produce an effect on later life (Dannefer, 2003; Sapin et al., 2007).

Results showed well-defined trends concerning the influence of life course determinants on vulnerability. Women with a familial trajectory marked by divorce, and with an occupational trajectory characterized by unemployment, housework and employee positions, were more likely to be vulnerable in late career. Similarly, individuals with health problems during the life course were also more likely to be vulnerable later in life. Conversely, people who benefited from the economic growth during the post-war period were less likely to experience vulnerability in older age.

Given these results, a first conclusion could be linked to the longitudinal approach used in this research. The empirical outcomes of this study allow us to recognize the significant role played by familial and occupational experiences of early and middle adulthood on later life. Thus, prospective studies looking to understand later life processes should focus on antecedent life processes rather than on circumstances in old age such as health or economic position.

Another conclusion relates to the cumulative disadvantage perspective. It is possible to note that vulnerability in late career is currently a status experienced by individuals who, during their life courses, accumulated characteristics that led to worse outcomes in later life. Among those characteristics are family issues, periods of absence from the labour market, working mostly as an employee and health problems.
It is noteworthy that the majority of these characteristics apply more often to women. This means that cumulative disadvantage is built into trajectories which impact much more negatively on women than men. Put another way, those family issues, career difficulties and stratification characteristics are effectively factors of cumulative disadvantage for women employees.

This gendered scenario has sociological and institutional implications. From a sociological perspective, this implies a gendered structure to the life course, i.e. the asymmetric working of family lives for men and women (Levy \& Widmer, 2013) can be observed not only in early and middle adulthood, but also in later life. This article suggests that social inequality between men and women particularly in terms of professional and familial trajectories - is an obstacle to women fitting into traditional male models of career development and ageing processes.

Secondly, from an institutional point of view, this gendered scenario indicates that although the Swiss labour market shows increasing rates of older workers as well as active ageing policies aiming to extend work life, both processes are clearly incompatible or discordant with the internal dynamics of the institution of the family. Put in illustrative terms, it seems that the Swiss labour market is structured in a way that harms those workers, usually women, who are compelled to interrupt their occupational courses due to family issues. Stopping their careers in early or middle adulthood means that women in Switzerland not only lose potential networks or labour expertise (Rosende \& Schoeni, 2012), but also-as this research has shown - experience more vulnerability in late career, which includes a greater likelihood of decreasing income, career interruption, part-time working and to late retirement.

In summary, the results obtained in this research contain relevant contributions for the life course study of vulnerability in late careers. First, the study puts forward a conception of vulnerability along four occupational dimensions, and secondly, it demonstrates the important role played by life trajectory and positional factors in occupational vulnerability in later life. Yet, there are clearly some characteristics of the current study that need to be considered and improved in prospective research. 
Relevant remaining questions relate to the possibility of analysing how the impact of the lifecourse determinants revealed varies according to the different industrial segments in later career. Also, it would be interesting to compare the results of the Swiss context with other gendered labour markets but with different welfare state arrangements. This is because liberal welfare states like Switzerland might or might not generate stronger labour vulnerability in women than corporatist welfare states. Further research could seek to answer these and other questions.

\section{Acknowledgements}

I wish to thank to Gaëlle Aeby, Dr. Jacques-Antoine Gauthier, Dr. Jean-Marie Le Goff, Prof. Dr. Daniel Oesch, Prof. Dr. Felix BühImann, Prof. Dr. Juan-Carlos Castillo, and especially to Cristobal Madero-Cabib, for their valuable inputs both on the content and shape of this article. This research has been financed by the NCCR LIVES Project, of the Swiss National Foundation of Science (FNS).

\section{References}

Blanchard, P., BühImann, F., \& Gauthier, J.-A. (2014). Advances in Sequence Analysis: Theory, Method, Applications. New York: Springer. http://dx.doi.org/10.1007/978-3-319-04969-4

Blau, P. (1977). A Macrosociological Theory of Social Structure. American Journal of Sociology, 83(1), $26-54$. http://dx.doi.org/10.1086/226505

Bukodi, E., \& Goldthorpe, J. (2011). Social Class Returns to Higher Education: Chances of Access to the Professional and Managerial Salariat for Men in Three British Birth Cohorts. Longitudinal and Life Course Studies, 2(2), 185-201.

Bütler, M., Huguenin, O., \& Teppa, F. (2004). What Triggers Early Retirement? Results from Swiss Pension Funds. Working Paper No. 4394, Centre for Economic Policy Research.

Castel, R. (2000). The Roads to Disaffiliation: Insecure Work and Vulnerable Relationships. International Journal of Urban and Regional Research, 24, 519-535. http://dx.doi.org/10.1111/1468-2427.00262

Castel, R. (2003). L'insécurité sociale: Qu'est-ce qu'être protégé? Paris: Seuil et La République des Idées.

Castel, R. (2009). La montée des incertitudes: Travail, protection, statut de l'individu. Paris: Editions du Seuil.

Candolfi, P., \& Chaze, J. P. (2008). Impact de la retraite anticipée sur les cotisations et les prestations de I'AVS. Genève: Université de Genève, Laboratoire d'économie appliquée.

Chan, S., \& Stevens, A. H. (2001). Job loss and employment patterns of older workers. Journal of Labor Economics, 19(2), 484-521. http://dx.doi.org/10.1086/319568

Chauvel, L. (1998). Le destin des générations, structure sociale et cohortes en France au XXe siècle. Paris: PUF.

Dancey, C., \& Reidy, J. (2004). Statistics Without Maths for Psychology. Harlow: Pearson.

Dannefer, D. (2003). Cumulative advantage/disadvantage and the life course: Cross-fertilizing age and social science theory. The Journals of Gerontology Series B: Psychological Sciences and Social Sciences, 58(6), 327-S337. http://dx.doi.org/10.1093/geronb/58.6.S327

Deville, J., \& Särndal, C. (1992). Calibration estimators in survey sampling. Journal of the American Statistical Association, 87, 376-382. http://dx.doi.org/10.1080/01621459.1992.10475217

Dorn, D., \& Sousa-Poza, A. (2004a). The Determinants of Early Retirement in Switzerland. Working Paper No. 98, Department of Economics, University of Saint Gallen.

Dorn, D., \& Sousa-Poza, A. (2004b). Motives for Early Retirement: Switzerland in an International Comparison. Working Paper No. 99, Department of Economics, University of Saint Gallen.

Dorn, D., \& Sousa-Poza, A. (2010). 'Voluntary' and 'Involuntary' Early Retirement: An International Analysis. Applied Economics, 42(4), 427-438. http://dx.doi.org/10.1080/00036840701663277

Feldman, D. (1994). The Decision to Retire Early: A Review and Conceptualization. Academy of Management Review, 19(2), 285-311.

Fischer, J., \& Sousa-Poza, A. (2006). The Institutional Determinants of Early Retirement in Europe. University of St. Gallen, Economics Discussion Paper No. 2006-08.

Gabadinho, A. Ritschard, G., Müller, N., \& Studer, M. (2011). Analyzing and Visualizing State Sequences in R with TraMineR. Journal of Statistical Software, 40(4), 1-37.

García, M., \& Schampheleire, J. (2002) The Inclusive Power of Standard and Non-Standard Work. In R. van Berkel, \& I. Hornemann (Eds.), Active Social Policies in the EU: Inclusion through Participation (pp. 73102). Bristol: Policy Press.

Gowan, M. (1998). A Preliminary Investigation of Factors Affecting Appraisal of the Decision to take Early Retirement. Journal of Employment Counseling, 35(3), 124-140. http://dx.doi.org/10.1002/j.21611920.1998.tb00994.x

Han, S., \& Moen, P. (1999). Clocking Out: Temporal Patterning of Retirement. American Journal of Sociology, 
105(1), 191-236. http://dx.doi.org/10.1086/210271

Hanel, B. (2010). Financial incentives to postpone retirement and further effects on employment. Evidence from a natural experiment. Labour Economics, 17, 474-86.

http://dx.doi.org/10.1016/i.labeco.2009.10.001

Hansen, H., Hespanha, P., Machado, C., \& van Berkel, R. (2002). Inclusion through Participation? Active Social Policies in the EU and Empirical Observations from Case Studies into Types of Work. In R. van Berkel, \& I. Hornemann (Eds.), Active Social Policies in the EU: Inclusion through Participation (pp. 103-136). Bristol: Policy Press.

Hirsch, B., Macpherson, D., \& Hardy, M. (2000). Occupational age structure and access for older workers. Industrial and Labour Relations Review, 53, 401-418. http://dx.doi.org/10.2307/2695966

Hyde, M., Ferrie, J., Higgs, P., Mein, G., \& Nazroo, J. (2004). The Effects of Pre-Retirement Factors and Retirement Route on Circumstances in Retirement: Findings from the Whitehall II Study. Ageing and Society, 24(2), 279-296. http://dx.doi.org/10.1017/S0144686X03001624

Kaufman, L., \& Rousseeuw, P. (1990). Finding Groups in Data: An Introduction to Cluster Analysis. New York: Wiley. http://dx.doi.org/10.1002/9780470316801

Kohli, M., Rein, M., Guillemard, A-M., \& Van Gunsteren H. (1991). Time for Retirement: Comparative Studies of Early Exit from the Labor Force. Cambridge: Cambridge University Press.

Kuehni, M., Rosende, M., \& Schoeni, C. (2013). Maintien en emploi et inégalités de sexe. Lien Social et Politiques, 69, 197-213. http://dx.doi.org/10.7202/1016492ar

Le Goff, J-M., Sapin, M., \& Camenisch, M. (2011). Intentions professionnelles des couples de Suisse romande après la naissance de leur premier enfant. In D. Joye, C. Pirinoli, D. Spini, \& E. Widmer (Eds.), Parcours de vie et insertions sociales (pp. 105-125). Zürich: Seismo.

Le Feuvre, N., Kuehni, M., Rosende, M., \& Schoeni, C. (2014). Le Genre du "vieillissement actif": du principe du traitement équitable à la multiplication des injonctions contradictoires. Swiss Journal of Sociology, 40(2), 307-324.

Levy, R., Joye, D., Guye, O., \& Kaufmann, V. (1997). Tous égaux? De la stratification aux representations. Zürich: Seismo.

Levy, R., Gauthier, J.-A., \& Widmer. E. (2006). Entre contraintes institutionnelle et domestique: Les parcours de vie masculins et féminins en Suisse. Revue canadienne de sociologie, 31, 461-89.

Levy, R., \& Widmer, E. (2013). Gendered Life Courses Between Individualization and Standardization. Wien: LIT Verlag.

Long, J.S. (1997). Regression Models for Categorical and Limited Dependent Variables. London: Sage Publications.

Madero-Cabib, I., \& Mora, C. (2011). Social Capital and Labour Inclusion. An Approximation to the Ascent Work Trajectories of Peruvian Migrants in Chile. Polis Review, 10(29), 147- 161.

Madero-Cabib, I., Gauthier, J-A., \& Le Goff, J.-M. (2013). Early, On-Time or Late? A Life Course Perspective on the Transition to Retirement, Paper prepared for the 11th European Sociological Association Conference, 2013, Torino, Italy.

Meyer, T., \& Pfau-Effinger. B (2006). Gender Arrangements and Pension Systems in Britain and Germany. Tracing change over five decades. International Journal of Ageing and Later Life, 1, 67-109. http://dx.doi.org/10.3384/ijal.1652-8670.061267

OECD. (2012). OECD.Stat database. Accessed 14th August 2014 from http://stats.oecd.org

OFS. (2012a). Newsletter No 1 Informations Démographiques. Suisse: Département fédéral de l'intérieur.

OFS. (2012b). Cotisations à l'AVS, à l'Al et aux APG. Suisse: Centre d'information AVS/AI).

OFS. (2012c). Cotisations des personnes sans activité lucrative à l'AVS, à l'Al et aux APG. Suisse: Centre d'information AVS/Al.

OFS. (2012d). Newsletter No 2 Informations Démographiques. Suisse: Département fédéral de l'intérieur.

O'Rand, A., \& Henretta, J. (1982). Delayed Career Entry, Industrial Pension Structure, and Early Retirement in a Cohort of Unmarried Women. American Sociological Review, 47, 365-373. http://dx.doi.org/10.2307/2094992

O'Reilly, J., \& Fagan, C. (1998). Part-Time Prospects: An International Comparison of Part-Time Work in Europe, North America and the Pacific Rim. London \& New York: Routledge. http://dx.doi.org/10.4324/9780203276105

Peterson, B., \& Harrell, F. (1990). Partial Proportional Odds Models for Ordinal Response Variables. Applied Statistics, 39, 205-217. http://dx.doi.org/10.2307/2347760

R Core Team. (2012). R: A Language and Environment for Statistical Computing. R Foundation for Statistical Computing. Accessed 14th August 2014 from www.R-project.org

Radl, J. (2013). Labour Market Exit and Social Stratification in Western Europe: The Effects of Social Class and Gender on the Timing of Retirement. European Sociological Review, 29(3), 654-668. http://dx.doi.org/10.1093/esr/jcs045

Riley, M. (1986). Men, Women, and the Lengthening of the Life Course. In A. Rossi (Ed.), Aging and the Life Course (pp. 333-347). New York: Aldine. 
Rosende, M., \& Schoeni, C. (2012). Seconde partie de carrière, régime de retraite et inégalités de sexe, le cas suisse. Revue française des affaires sociales, 2-3, 130-147.

Sapin, M., Spini, D., \& Widmer, E. (2007). Les parcours de vie: de l'adolescence au grand âge. Lausanne: Savoir suisse.

Schröder, M. (2011). Retrospective Data Collection in the Survey of Health, Ageing and Retirement in Europe. SHARELIFE Methodology. Mannheim: MEA.

Solon, G., Haider, S. J., \& Wooldridge, J. (2013). What are we weighting for? (No. w18859). National Bureau of Economic Research. http://dx.doi.org/10.3386/w18859

Spini, D., Hanappi, D., Bernardi, L., Oris, M., \& Bickel, J-F. (2013). Vulnerability across the Life Course: A Theoretical Framework and Research Directions. Working LIVES Paper, No. 2013/27.

Van Berkel, R., Hornemann, I., \& Williams, C. (2002). The Concept of Inclusion/Exclusion and the Concept of Work. In R. van Berkel, \& I. Hornemann (Eds.), Active Social Policies in the EU: Inclusion through Participation (pp. 15-44). Bristol: Policy Press.

Ward, J. (1963). Hierarchical grouping to optimize an objective function. Journal of the American Statistical Association, 58(301), 236-244. http://dx.doi.org/10.1080/01621459.1963.10500845

\section{Appendix 1. Weighted frequencies in the study sample and in the Swiss sample of SHARELIFE}

\begin{tabular}{|c|c|c|}
\hline Covariates & $\begin{array}{l}\text { Weighted Frequencies in } \\
\text { Study Sample }(\mathrm{N}=451)\end{array}$ & $\begin{array}{l}\text { Weighted Frequencies in } \\
\text { Swiss Sample of SHARELIFE }(\mathrm{N}=1296)\end{array}$ \\
\hline III-health periods & 0: No (89.8\%), 1: Yes (10.2\%) & $0:$ No $(90.3 \%), 1$ : Yes (9.7\%) \\
\hline Financial hardship periods & 0: No (69.3\%); 1: Yes (30.7\%) & 0: No (68.5\%); 1: Yes (31.5\%) \\
\hline Gender & 1: Men (60.3\%), 0: Women (39.7\%) & 1: Men (45.9\%), 0: Women (54.1\%) \\
\hline $\begin{array}{l}\text { Educational position relative to } \\
\text { others in maths during childhood }\end{array}$ & $\begin{array}{c}\text { 1: Better or Much Better ( } 88.8 \%) \text {, } \\
0 \text { : Much worse, Worse or About the same } \\
(11.2 \%)\end{array}$ & $\begin{array}{c}\text { 1: Better or Much Better }(86.4 \%) \text {, } \\
\text { 0: Much worse, Worse or About the same } \\
(13.6 \%)\end{array}$ \\
\hline $\begin{array}{l}\text { Educational position relative to } \\
\text { others in language during } \\
\text { childhood }\end{array}$ & $\begin{array}{l}\text { 1: Better or Much Better }(86.4 \%) \text {, } \\
\text { 0: Much worse, Worse or About the same } \\
(13.6 \%)\end{array}$ & $\begin{array}{l}\text { 1: Better or Much Better }(87.4 \%) \text {, } \\
0: \text { Much worse, Worse or About the same } \\
(12.6 \%)\end{array}$ \\
\hline $\begin{array}{l}\text { Number of books in home in } \\
\text { childhood }\end{array}$ & $\begin{array}{l}\text { 1: } 26 \text { books or more }(83.1 \%) \\
0 \text { : Less than } 26 \text { books }(16.9 \%)\end{array}$ & $\begin{array}{l}\text { 1: } 26 \text { books or more }(77.6 \%) \\
0: \text { Less than } 26 \text { books }(22.4 \%)\end{array}$ \\
\hline Birth Cohort & $\begin{array}{c}\text { 1: Before } 1930(27.4 \%), 2: 1931-1936 \\
\text { (23.4\%), 3:1936-1942 (29.8\%) } \\
\text { 4: After } 1942(19.3 \%)\end{array}$ & $\begin{array}{c}\text { 1: Before } 1930(17.5 \%), 2: 1931-1936 \\
\begin{array}{c}(12.8 \%), 3: 1936-1942(15.7 \%) \\
4: \text { After } 1942(54.1 \%)\end{array}\end{array}$ \\
\hline
\end{tabular}




\section{Appendix 2. Types of familial trajectories in Switzerland between ages 20 to 49}

Familial Trajectory 1. Marriage \& One Child

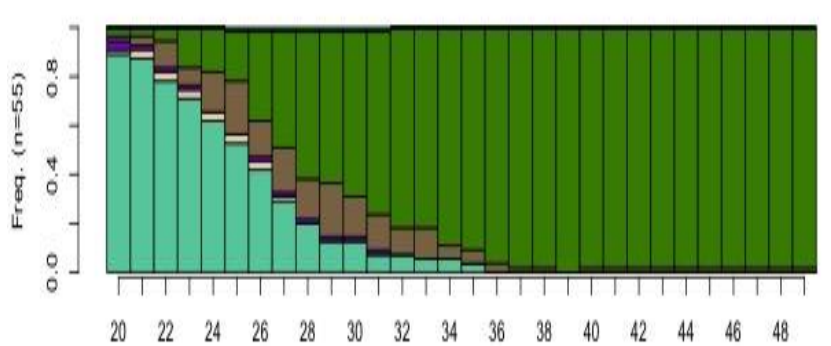

Familial Trajectory 3. Marriage \& Three or More Children

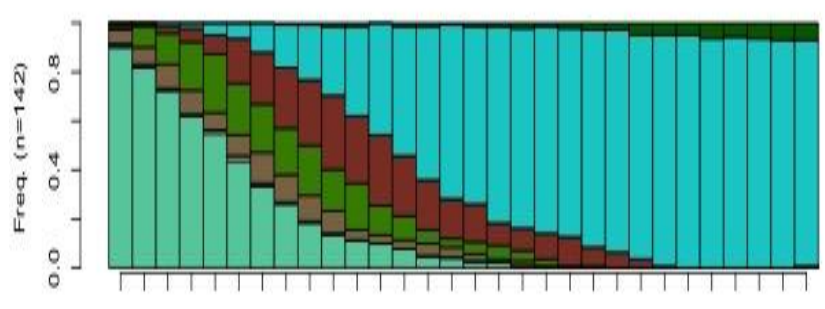

$\begin{array}{lllllllllllllll}20 & 22 & 24 & 26 & 28 & 30 & 32 & 34 & 36 & 38 & 40 & 42 & 44 & 46 & 48\end{array}$

Familial Trajectory 5 . Marriage \& Divorce

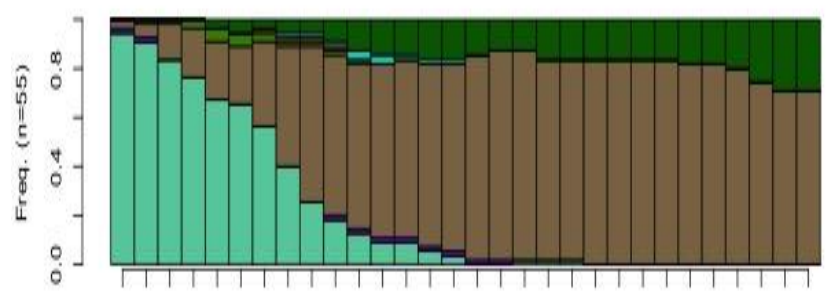

$\begin{array}{lllllllllllllll}20 & 22 & 24 & 26 & 28 & 30 & 32 & 34 & 36 & 38 & 40 & 42 & 44 & 46 & 48\end{array}$
Familial Trajectory 2. Marriage \& Two Children

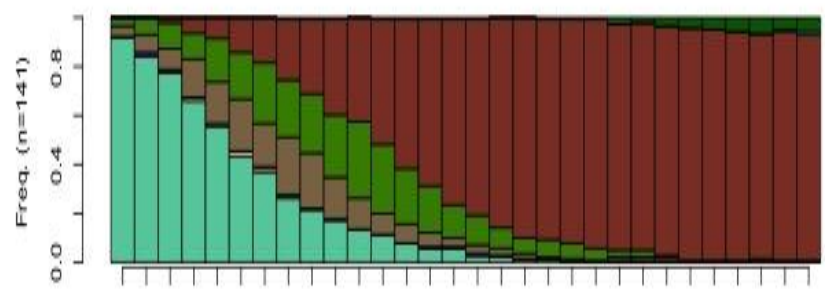

$\begin{array}{lllllllllllllll}20 & 22 & 24 & 26 & 28 & 30 & 32 & 34 & 36 & 38 & 40 & 42 & 44 & 46 & 48\end{array}$

Familial Trajectory 4. Solo Living

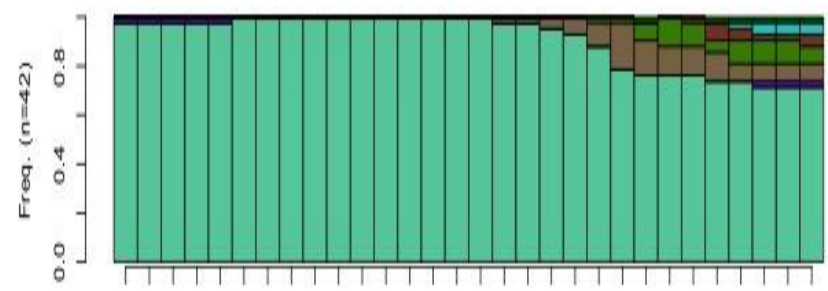

$\begin{array}{lllllllllllllll}20 & 22 & 24 & 26 & 28 & 30 & 32 & 34 & 36 & 38 & 40 & 42 & 44 & 46 & 48\end{array}$

Familial Trajectory 6. Late Marriage

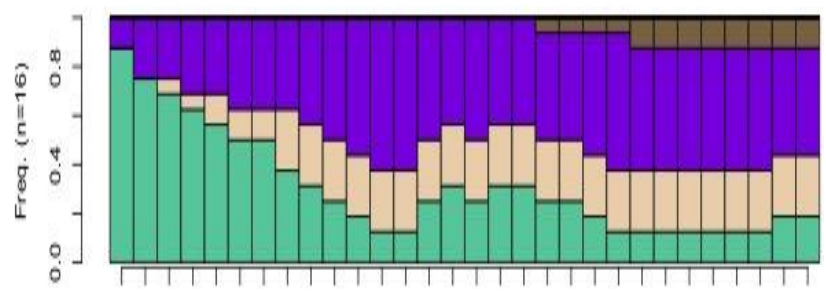

$\begin{array}{lllllllllllllll}20 & 22 & 24 & 26 & 28 & 30 & 32 & 34 & 36 & 38 & 40 & 42 & 44 & 46 & 48\end{array}$

$\underline{\text { Categories }}$

\begin{tabular}{|ll|}
\hline Solo & Marriage \& 1 Child \\
Children & Marriage \& 2 Children \\
Non-Cohab or Cohab & Marriage \& 3 or More Children \\
Marriage & Divorce
\end{tabular}




\section{Appendix 3. Types of occupational trajectories in Switzerland between ages 20 to 49}

Occupational Trajectory 1. Service Employee Careers

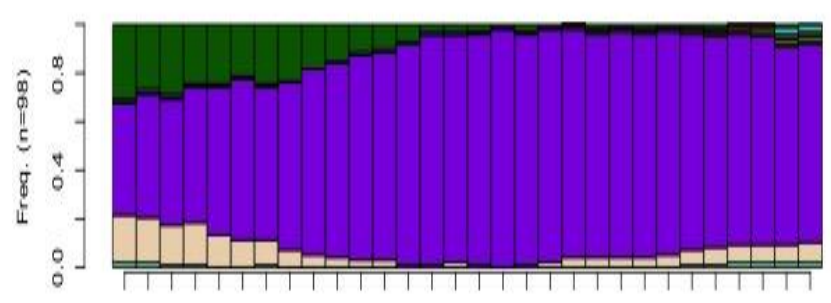

$\begin{array}{lllllllllllllll}20 & 22 & 24 & 26 & 28 & 30 & 32 & 34 & 36 & 38 & 40 & 42 & 44 & 46 & 48\end{array}$

Occupational Trajectory 3. Professional Employee Careers

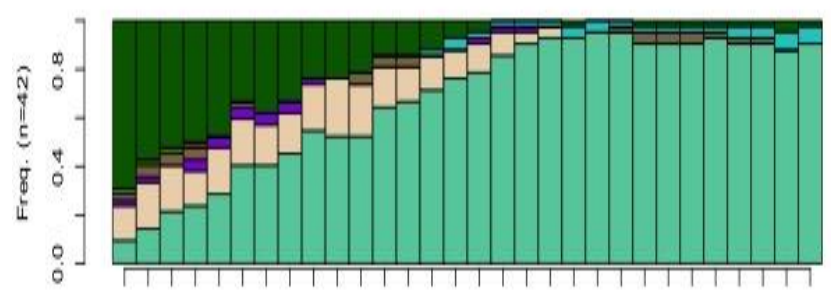

$\begin{array}{lllllllllllllll}20 & 22 & 24 & 26 & 28 & 30 & 32 & 34 & 36 & 38 & 40 & 42 & 44 & 46 & 48\end{array}$

Occupational Trajectory 5. From Employee to Self-Employed

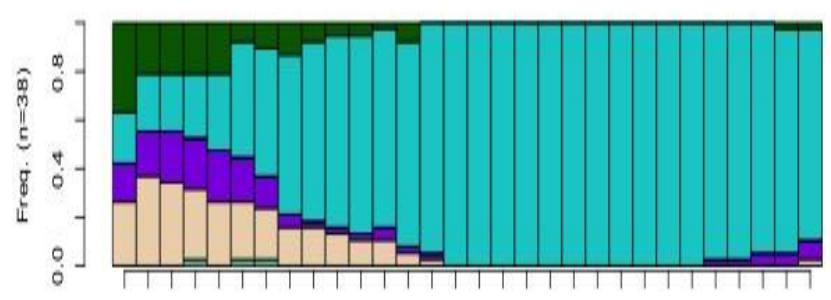

$\begin{array}{lllllllllllllll}20 & 22 & 24 & 26 & 28 & 30 & 32 & 34 & 36 & 38 & 40 & 42 & 44 & 46 & 48\end{array}$

Occupational Trajectory 7. Technician Civil-Servant Careers

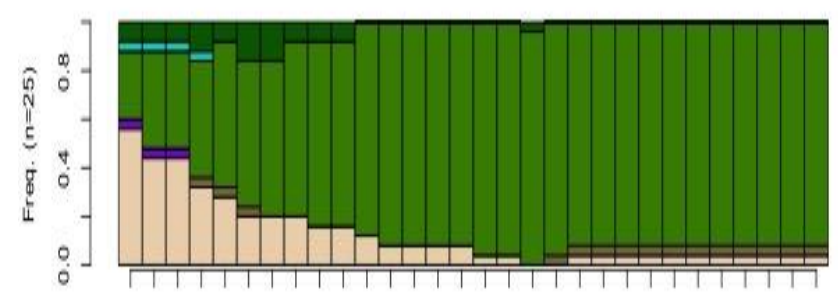

$\begin{array}{lllllllllllllll}20 & 22 & 24 & 26 & 28 & 30 & 32 & 34 & 36 & 38 & 40 & 42 & 44 & 46 & 48\end{array}$
Occupational Trajectory 2. Technician Employee Careers

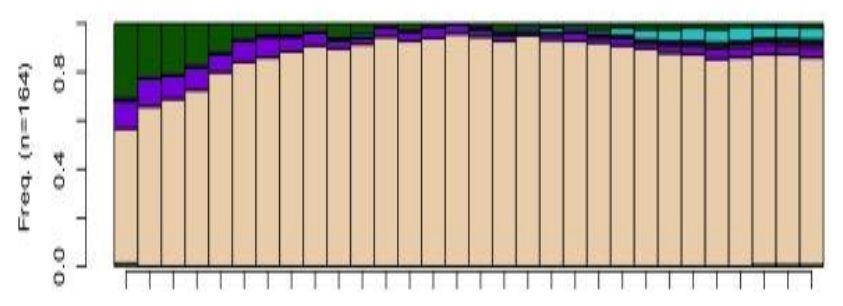

$\begin{array}{lllllllllllllll}20 & 22 & 24 & 26 & 28 & 30 & 32 & 34 & 36 & 38 & 40 & 42 & 44 & 46 & 48\end{array}$

Occupational Trajectory 4. Interrupted Careers \& Non-Careers

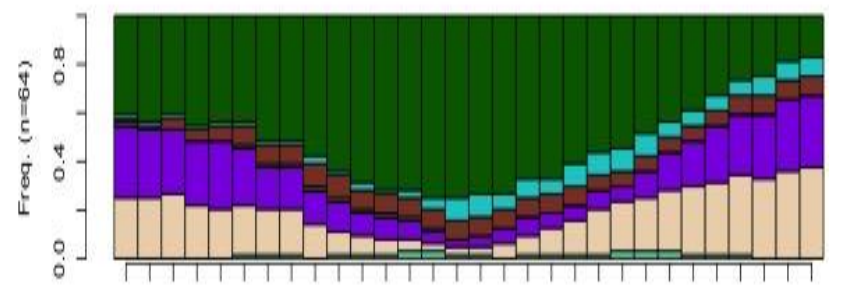

$\begin{array}{lllllllllllllll}20 & 22 & 24 & 26 & 28 & 30 & 32 & 34 & 36 & 38 & 40 & 42 & 44 & 46 & 48\end{array}$

Occupational Trajectory 6. Professional Civil-Servant Careers

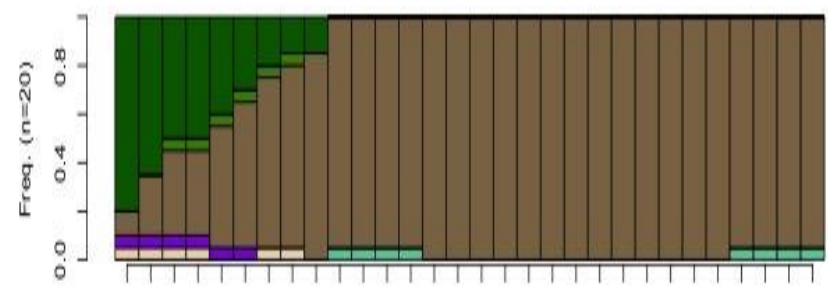

$\begin{array}{lllllllllllllll}20 & 22 & 24 & 26 & 28 & 30 & 32 & 34 & 36 & 38 & 40 & 42 & 44 & 46 & 48\end{array}$

$\underline{\text { Categories }}$

- Professional Employee - Service Civ-Serv

- Technician Employee $\square$ Self-Employed

- Service Employee Out of Labour Market

- Professional Civ-Serv \missing

- Technician Civ-Serv 